\title{
Transcontextual Narratives of Inclusion: Mediating Feminist and Anti-Feminist Rhetoric
}

\author{
Verna Marina Ehret \\ Mercyhurst University, 501 E. 38th St., Erie, PA 16546, USA; vehret@mercyhurst.edu
}

Received: 31 March 2018; Accepted: 15 May 2018; Published: 16 May 2018

\begin{abstract}
In seeking a path to mediating feminist and anti-feminist narratives, one must begin with a framework of the method of narrative analysis being used. Using the works of such thinkers as Paul Ricoeur and Richard Kearney, I argue that human self-understanding and therefore sense of identity is narrative dependent. While this idea has its critics, in the framework of the central question of this essay narrative theory is a particularly productive tool. The story that I tell that gives me identity is not only a story about the surface. It is embedded in my being. I do not simply have a story, I am a story and create my world through that story. Narrative is a part of the ontological structure of being human and the ontic experience of being in the world. One narrates one's life not in the sense of a movie voiceover, but rather as a reflective and reflexive understanding of oneself. Kearney's work in Anatheism is particularly useful for this discussion. While Kearney's interest is in the dialectical move from theism to atheism to a synthesis that is an atheist-informed theism, one can see the same trajectory at work in feminism and anti-feminism. If one begins with patriarchy and moves to feminism, the next step becomes anti-feminism informed by feminism. However, there is still room for an additional dialectical move, to regain a feminism that invites in its detractors and reshapes the collective narratives that impact how we interact with each other in community.
\end{abstract}

Keywords: transcontextual narrative; performative narrative; reconciliation

"It would have been easier if he had just actually spit in my face and asked me to get him coffee." This was the beginning of a conversation with a colleague recently after a misogynistic microaggression. The point being made was that while anyone who was paying attention would be able to see the sexism at work in an exchange with a male colleague, she also knew that the burden of proof fell to her. There were a thousand ways one could rationalize away the experience as not having been one of sexism in the work place. To explain to this perpetrator, who has a history of subtle sexism in the work place, that what he did was sexist, marginalizing, and demeaning of her value, was not going to be easy. He had been called out for this kind of behavior at least twice before but nothing had changed. He was a self-proclaimed feminist. Therefore, he could not be sexist, went the narrative. Had he been more overt, more aggressive in his sexism, the task of calling it out would have been much easier in that she could prove it. Although it would not have been any easier to change the behavior or the narrative behind it. However, that is not what happened. The two colleagues live in different and often conflicting narrative structures, and the challenge that faced her was how to bridge the gap between these two very disparate narratives in a way that did not destroy the possibility of a good working relationship with someone who in many other ways she respected. It is the myriad of experiences of these conflicting narratives that happen daily that is the impetus for this essay.

When I first started working on this project, I thought, "Well I am not a feminist scholar, but I am a woman who thinks and a feminist person. Is that sufficient?" Then I started reading in current feminist theory and realized that was not sufficient. There are deep traditions that make up the narratives of feminism that shape me whether or not I am aware of them. Background in feminist theory provides not only data but also the language to be able to address the tension between these narratives. The 
claim I intend to make in this essay is that transcontextual narratives are narratives that create new frames of meaning in the space between conflicting narratives. They overlap them, drawing people into the in-between space of meaning and understanding. These narratives become performative of reconciliation because they create the world anew. Performative narratives enact reality, and so a transcontextual performative narrative of reconciliation is a way of being in the world through our narrative identities where they begin to overlap with those who are quite different from us. It is important to note that there is no single voice of feminism or anti-feminism. Feminism embraces the tremendous diversity of women's experiences and anti-feminism can be both intentional and unconscious. However, through the course of this essay I intend to show a method that can be applied in a wide variety of circumstances to build communities of inclusion.

Part of the challenge of a project such as this is language itself. The formal language of a field of study can create a jargon that both gives voice to inchoate ideas and can get in the way of understanding. This essay presents an apparent binary relationship between "feminist" and "anti-feminist." However, this project proposes an alternative to binary ways of thinking. The alternative creates community. There are limitations to framing the conversation in binary terms. It seems to arbitrarily imply only two types of voices in this discussion and can lead to further marginalization of the voices not included. However, this binary is not intended to be an ontological taxonomy. Rather, it is providing a more phenomenological heuristic to provide categories that encompass a broad swath of voices in the issues of feminism. Lived reality shows this kind of bifurcation of "feminist vs. anti-feminist" rising to the forefront of the discussion. While the categories should not be taken as absolutes, I am arguing that if this method works in one instance it can be translated into others. What I am providing is a theoretical framework for building performatives narratives that break through the rigid bifurcation of reality that every day seems to get stronger.

One can also argue that the way feminist narratives are constructed is a part of what anti-feminism rejects because the vocabulary loses something important in translation from one narrative to the other. If anti-feminist narratives take as a basic assumption that feminist narratives are anti-male, then the feminist narratives are perceived as a threat to the male identity, which contributes to the creation of anti-feminist narratives. Modifying some of the work of Richard Kearney on anatheism, there are stages of development that will allow one to move through the anti-feminist counter narratives to a more enlightened and inclusive feminism (Kearney 2010). It is my claim that the beginning of a performative narrative of reconciliation between feminist and anti-feminist narratives requires reinforcing and claiming the identity of feminist as something positive rather than something to be feared.

The concerns about reclaiming feminism, or as Kearney might put it an anti-feminism, were brought to the forefront of public discussion with the \#metoo movement, its supporters, and its detractors. A lightening rod for the clash of feminist and anti-feminist narratives was Aziz Ansari, an actor whose feminist credentials seemed fairly credible for a male Hollywood actor. However, then a story came out about him seeming to misread cues where his position of power created imbalance in a dating situation. While some use this story as an example of the systemic embeddedness of gender imbalance, others see it as the creation of a "sex panic" where a man innocently misunderstood some cues and is now being persecuted (Hamblin 2018). Others have used Al Franken, former Senator from Minnesota, as another example of accusations of gender power imbalance and "rape culture" gone too far and destroying good men. This \#metoo movement has brought the conversations of feminist and antifeminist rhetoric vividly into the public sphere even for those without social media. While various questions can be raised about the impact of social media in turning narratives into performative creations of alternative realities, for the purposes of this article social media is one among many media embedding these narratives in people's consciousness, forcing them to take a side, to choose a narrative that they claim as a part of their being. In doing so they risk losing parts of themselves in the relationships lost because friends or family chose the other side (Wood 2018). 
At the level of the academy, these discussions turn to the value of a person's work against the things a person has done. Can we, for example, still use the valuable insights of John Howard Yoder who argued for the value of feminist voices in theology while at the same time being guilty of violence against women that led to a disciplinary process against him (Guth 2015)? Is his work more important than his own acts against women? While some have argued that continuing to use his work re-victimizes the women by his fame remaining intact, others have argued that the value of his work is separate from the person (Guth 2015).

The further complicating factor of all of these discussions is the power dynamic at work in each of these situations, including the story that opened this essay. The trajectory of this essay will be focused on the ways feminist narratives can be reframed to be transcontextual in that they reach beyond the specific experience of individuals without denying that individuality. However, the individuality of the stories remains important. A transcontextual narrative is different from a meta-narrative, and the goal in creating them is to build shared space, but not a dominating new narrative. These transcontextual narratives are meant to also be performative of reconciliation. In creating a shared space that invites the experiences of difference into a bridge of community the performative narrative creates reconciliation. However, again, this essay focuses on the way feminist narratives can initiate that performative narrative of reconciliation.

So, one could justifiably ask if this very activity simply reinforces the power dynamic that has created the narratives of estrangement in the first place? Does placing the burden of reconciliation on feminist narratives simply reinforce the notion that women must apologize for being women? These are legitimate concerns. However, my response to these concerns is that if we are going to move beyond a binary mode of thinking, feminist vs. anti-feminist, reconciliation that arises through the creation of shared space through new narrative frames is necessary and must arise from the narratives already seeking inclusion rather than dominion. The rhetoric of anti-feminism is based in a power dynamic that sees equality as a loss, a point I will explain later in this essay. There is no motivation, then, from that point of view to seek inclusion and reconciliation because it is the language of inclusion that anti-feminism is currently rejecting. While an unfortunate reality, and one that can in some sense reinforce gender dynamics, it is still the reality we face that the first move must begin somewhere, and feminist thinkers and actors have a greater motivation to do so.

In the opening example of this essay, the power dynamic is clear. However, experience has shown that there is no recognition of a problematic behavior on the man's side in that example. In addition, made aware of it, he is both surprised to be seen in that way and offended for having been called out on a blatant act of sexism because he is a self-described feminist. While this essay cannot address all of the anti-feminist rhetoric of self-proclaimed feminists, it does acknowledge that the very existence of this category indicates why blatant anti-feminists are often less likely to initiate this reconciliatory conversation.

Moreover, in taking on the responsibility of reshaping the narrative, feminists seeking reconciliation and community take control of the trans-contextual bridge. In that act, the anti-feminist is being invited into a feminist narrative, an act which can shift the power dynamic and more successfully be performative of reconciliation in a way that community is built than if the person leading the discussion does not have reconciliation and inclusion as a motivation.

In choosing sides in these debates one must create a narrative that allows one to justify one's perspective on the world and to encourage others to incorporate that perspective into their own stories. Narrative is performative. It creates reality. In addition, we have a multitude of examples where it is performative of estrangement. However, can it also be performative of reconciliation? That is the central question with which our society must wrestle because the answer to that question holds in it concerns about justice, human rights, human dignity, and human flourishing. Who is allowed to flourish in our society through the narratives that shape our cultural frames and identity? 


\section{Transcontextual Narratives and Performative Narratives of Reconciliation}

In seeking a path to mediating feminist and anti-feminist narratives, one must begin with a framework of the method of narrative analysis being used. Using the works of such thinkers as Paul Ricoeur and Richard Kearney, I argue that human self-understanding and therefore sense of identity is narrative dependent. While this idea has its critics, in the framework of the central question of this essay narrative theory is a particularly productive tool. The story that I tell that gives me identity is not only a story about the surface. It is embedded in my being. I do not simply have a story, I am a story and create my world through that story (Lange 2016). Narrative is a part of the ontological structure of being human and the ontic experience of being in the world. One narrates one's life not in the sense of a movie voiceover, but rather as a reflective and reflexive understanding of oneself (Downey 2012). Kearney's work in anatheism is particularly useful for this discussion. While Kearney's interest is in the dialectical move from theism to atheism to a synthesis that is an atheist-informed theism, one can see the same trajectory at work in feminism and anti-feminism. If one begins with patriarchy and moves to feminism, the next step becomes anti-feminism informed by feminism. However, there is still room for an additional dialectical move, to regain a feminism that takes into account masculinity and anti-feminist narratives. Kearney identifies five moments in this dialectical process, separated for analysis, but in practice often happening simultaneously: Imagination, humor, commitment, discernment, and hospitality (Kearney 2010). These five will be explored in the penultimate section of this essay.

Challenges to the claim that human beings are a narrative include the claim that a human life is not a simple plot line. Postmodern theorists have broken down narrative into two types. Meta-narrative is the idea that a single narrative can encapsulate all of human truth, seen most clearly in religious claims to a single perspective of religious truth that explains the whole of human experience. In the contemporary world the meta-narrative is generally the domain of hypertheism (Klemm and William 2008). Hypertheism seeks the kind of universal theory of truth where those who agree are included in salvation and those who disagree are excluded from the community and salvation. In theological feminist theory, the concern with meta-narrative is kyriarchy, the oppressive application of a single way of understanding the message of, for example, Christian truth that marginalizes and even dismisses women's experiences and voices. Meta-narrative as kyriarchy is rejected as an untenable way of interpreting narrative because it creates narrative identities of insider and outsider, primary and secondary citizens or members of a community. The recognition of the multiplicity of narratives and truths led postmodern theorists to the idea of the little or contextual narrative (Gehlin 2010). The claim is that truth is not one and as individuals our stories themselves are not singular. Each person is a kind of hybridity, a blend of narratives unfolding simultaneously in a kaleidoscope of stories that flow together and separate, creating a blended image that changes with each angle one takes. The challenge of the contextual narrative is infinite fracturing of the individual and the community.

If each person has multiple perspectives, how does the person blend them into a unified person, to be a hybrid and complex self? The contextual narrative shows us that we do and do not know ourselves because we are and are not a unified self. It is because of the multiplicity of our narratives that one can see oneself as a whole and consistent person while holding conflicting interpretations of the world, for example, that women are equal to men and at the same time marginalize the accomplishments of the women one works with. The challenge faced by an attempt to mediate between feminist and anti-feminist narratives is not only the conflict between the groups who hold them, but also the internal conflict where both the feminist narrative can be anti-feminist and the anti-feminist narrative can claim the equality of women is already achieved and assumed and feminists are making a case for a problem that no longer exists.

This is where the transcontextual narrative enters. The idea of the transcontextual narrative is that it takes the language of competing narratives and seeks shared ground within them, creating an interpretive frame that invites all into this new frame (Ehret 2013). Taping into the pre-existing meanings of the symbols of these narratives, putting these symbols into a new frame draws new 
meanings and opens shared space. In the process, the transcontextual narrative can become a part of the matrix of each individual's narratives that shape their identity. Of course, such a notion is highly idealistic, but the ideal is also possible within real human experience, as will be seen in some of the mediating options explored in this essay. It is the proposal of this essay that transcontextual narratives move from the ideal to the real when they are performative of reconciliation.

The addition of the performative element is the claim that the ontological nature of narrative in individual identity is also in communal identity (Yang 2016). Some narratives as they unfold in the public domain create the reality they express. In the most disturbing form of performative narratives one can look at the performative narratives of estrangement. When one's narrative creates a feeling of exclusion in another and spreads to others whose own narrative participates in that narrative, a performative narrative unfolds. The recent growth in hate crimes traced back to narratives of racial, religious, or gender exclusion is an example of this type of performative narrative (Southern Poverty Law Center 2017). However, if a narrative can break apart, it can also bring together. A performative narrative of reconciliation is one that creates the conditions for an unfolding reality of reconciliation between individuals and groups that have resisted each other. Communities coming together to support each other after a tragedy see reconciliation of differences through the shared experience. The goal of this essay is to try to create the conditions for performative narratives of reconciliation without requiring a tragedy first.

\section{Examples of Feminist Narratives}

The creation of a transcontextual narrative requires first understanding the original narratives at work. It is, however, important to recognize that even in the case of the category of feminist narratives that it is intentionally a plural (Hamid 2006). There is not a single voice of feminism. However, it is possible to discern patterns from the multiplicity of narratives and the conversations that happen between feminist thinkers. Below is a series of feminist writers constructing various versions of feminist narratives, and in reading these one finds certain recurring themes: gender justice, oppression, patriarchy, kyriarchy, hegemonic masculinity, liberation, agency, diversity of experiences, and the challenges of theological narratives to simultaneously include and exclude.

Gender justice is, not surprisingly, a central theme in feminist narratives. Religious meta-narratives have been used throughout human history to marginalize the voices of women. Certain readings of Hebrew Bible or New Testament, for example, become a part of cultural memory-the accepted truths of a community about the reality that God has created. However, the texts themselves do not always fit well with cultural memory, and feminist biblical scholars have unpacked that tension between text and cultural narrative. Feminist narratives based on scriptural study have argued that the dominion of men described in Genesis 3, for example, is often used to justify the authority of men over women. However, that narrative comes from a misreading of the text. The created nature of human beings as described in Genesis is one of equality. The dominion of men is based in the fallen nature of humanity, humanity that has already been estranged from God. Male superiority is not, then, the created order, but the result of sin (Jovic 2015). Gender justice, it is argued, is the proper nature of things and the marginalization of women comes from a misunderstanding of biology, theology, and psychology.

A second theme of feminist narratives within a theological domain is kyriarchy, which encompasses the themes of patriarchy and oppression and overlaps the theme of gender justice. Kyriarchy is the particular form of patriarchy that uses religious tradition and message as a way to show women that their secondary status relative to men was ordained by God. They are not oppressed, they are just fulfilling the roles God has given them. This particular form of patriarchy that marginalizes women's voices and roles has a very long history in Western religions and Christianity in particular (with which I am most familiar). Kyriarchy highlights the role of oppressive religious narratives and the ways they are used to justify violence against women not only in spiritual but also in physical ways. This kyriarchy, as described by Schüssler Fiorenza, requires a kind of liberation narrative for women, to be set free from the confines of tradition (Nienhuis 2009). The response, 
Nienhuis argues, is "The hermeneutic of creative imagination must be employed in concert with all others because kyriarchal ideologies can 'colonize the imagination'. If we reimagine what might have happened if the Jesuits had employed Schüssler Fiorenza's hermeneutics, we begin to construct a resistance strategy" (Nienhuis 2009). Liberation and resistance are therefore connected themes of feminist narratives in response to kyriarchy.

Embedded in kyriarchy and patriarchy, according to feminist narratives, is hegemonic masculinity, which is "defined as valorized male attributes like rationality and aggression associated with hyper-masculinized institutions and cultures, such as those associated with the military" (Poloni-Staudinger and Ortbals 2014). This theme of feminist narratives is also a theme of masculine narratives (see "wrath of Achilles" below). In feminist narratives hegemonic masculinity is often seen in the public understanding of women, for example how women leaders are portrayed in the media as opposed to how male leaders are portrayed. Studies of media portrayals of women show that women's agency is minimized by hegemonic framing. "Framing refers to how elites or the media construct and present reality. Frames present 'little tacit theories about what exists, what happens, and what matters' [21]. They articulate how reality is defined and interpreted by various actors and institutions [7]" (Poloni-Staudinger and Ortbals 2014). The power of media is performative narrative. The ubiquity of hegemonic masculinity presented in the media allows that to become the frame by which public female figures are evaluated and the examples they are allowed to be for girls and other women. These hegemonic masculine narratives create the reality to which feminist narratives must respond in order to create the gender justice with which this section began. However, despite these recurring themes, there is also tremendous diversity in what might be considered feminist. In contemporary feminist narratives, that very diversity of perspectives has itself become a common theme in order to engage women's experiences across social, political, economic, and geographical lines more fully. This diversity of perspectives responding to hegemonic masculinity and kyriarchy engages the narratives in ever more extreme versions of these themes as they become greater justifications for violence against women. In these discussions, the greater depths of feminist narratives can be explored.

The narratives of feminism unfold not simply in the individual voices of feminist thinkers, but also in their engagement with each other. For those of us who are regularly in classrooms, we find again and again both female and male students who deny that sexism is a problem and see "feminist" as an insult and a dangerous idea. Combating the rejection of feminism in the name of an imagined completion of the feminist project leaves new generations vulnerable to the old traps of patriarchy, to excuse behavior that marginalizes women as "no big deal." The engagement with feminist thought across time thus becomes an important element of the narrative itself (Rigoglioso 2011). Many of the articles read for this project were by prominent feminist thinkers engaging each other's work across time. Among these essays we find powerful arguments for the importance of identifying oneself within the feminist tradition and honoring the figures who have come before. As Carol Christ notes, of Judith Plaskow, " ... feminist theology is foremost the process of women becoming selves in religious communities" (Christ 2011). The narratives of religion that create belonging and community, when read through a feminist lens, are performative. They create the conditions for women to realize their full being and to imagine change in the world. Nancy Pineda-Madrid looks to the power of the Mirabal sisters in the history of feminism, assassinated for their work in fighting for justice for women in the Dominican Republic, as models to be claimed and celebrated (Pineda-Madrid 2011). This discussion builds on Elisabeth Schüssler Fiorenza who was honoring in her writing the work of Catharina Halkes and the importance of recognizing and celebrating the tradition of feminism, for it too, is a tradition. In addition, that notion of tradition, of being connected to the past and pointing into the future, is essential for the strength of feminist narratives if there is to be reconciliation. As will be seen in a moment, one of the critiques of feminism is that it rejects tradition. However, it is itself tradition. Schüssler Fiorenza says, "In a context of capitalist globalization and fundamentalist heterosexist hierarchalism, I continue to argue that in the face of progressive social injustice feminist the*logy must be articulated in one way or another as a critical the ${ }^{*} \log y$ of liberation or emancipation, that is, as a radical democratic discourse 
of conscientization, self-respect, and transformation" (Schüssler Fiorenza 2011). She goes on to argue that, "Patriarchal or better kyriarchal power structures rob wo/men of their intellectual traditions. Consequently, the next feminist generations cannot learn from the thought of their predecessors, but are constantly forced to reinvent the intellectual wheel" (Schüssler Fiorenza 2011). As she points toward the past and tradition, Schüssler Fiorenza also looks to the future unfolding of feminist narratives. While the past relied on images of motherhood to counter the fatherhood of God, notions of motherhood also marginalize and exclude women, creating a second-class status for women without children for whatever reason that might be. The language of religious narratives cannot, therefore, simply be converted from masculine to feminine terms, but the frames of the language must also be engaged (Powell 2015). If the goal is justice and flourishing and the image of God is used as a model for the power of women, an image that also marginalizes women who do not fit that mold itself becomes problematic (Schüssler Fiorenza 2011).

In the process of unfolding feminist narratives, one moves from that which they argue against—patriarchy and hegemonic masculinity—to that which they argue for-liberation, agency, and the gender justice with which this section began. Exploring the work of Letty Russel, one finds the proposal that education is the path toward liberation. "Education is seen as a process of liberation in community that includes conscientization as 'learning to perceive the social, economic, political contradictions and to take action against the oppressive elements of reality'. Using Freire's ideas, Russel reflected on how people throughout the world have struggled to 'become partners who share together in the journey of freedom' with the hope of 'sharing their future'" (Brady 2008). The feminist narratives from theology risk accepting a singular narrative that can over-simplify questions of feminism, limiting them to a single religious tradition and moreover a single interpretation of a single religious tradition.

To narrate within a religious tradition, as many of these feminist thinkers do, and beyond it is a challenge that each of these feminist and anti-feminist narratives face to varying degrees (Brady 2008). Religion can be empowering and disempowering, so in addition to liberation, the theme of agency recurs in feminist narratives. The interpretive path one takes through religious traditions can provide opportunities, by the very act of reconfiguration, of claiming agency in the creation of larger community narratives that incorporate feminist concerns (Avishai 2016).

Feminist narratives take a variety of forms. Many have the commonality of addressing the marginalization and even oppression of women. However, a current critique of Western feminism is its racial and cultural bias. So, in understanding feminist narratives it is important to keep in mind the wide array of voices at work. Ana Patricia Rodriguez, for example, writes about the, "Fiction of Solidarity" in feminist narratives that become forms of intellectual colonialism. Her analysis of intersectionality and hybridity in feminist narratives points to the ways in which women live in between worlds and cross borders. In doing so both physically and culturally, they bring a wide array of experiences to these narratives. Rodriguez provides an analysis of these ideas as presented in films and novels that explore identity construction of women living across borders and seeking connection and affinity across the borders. These works are also critical of the imperialism of the United States that ignores the suffering of women in Central and South America (Rodriguez 2008). One thing that recurs as a theme is the crime of being brown, the assumption by INS agents (currently ICE) that those who crossed the southern border of the United States are criminals. That assumption provides an additional complication to the experience of being female in relation to the patriarchy not faced by a US-born woman of English descent. Rodríguez's analysis shows the complexity of attempts at solidarity across gender, national, and racial boarders. Solidarity narratives are fragile, broken by the smallest differences and therefore difficult to sustain. As much as we may want people to all start from the same level, the reality of our world is imbalance of power in social, political, and economic domains. This desire for solidarity and symmetry amid the reality of asymmetry is a part of the path of agency and liberation.

However, in the midst of these descriptions of patterns and diversity within feminist narratives, one thing that can get lost is politically, religiously, or socially conservative feminist voices. So, to add 
to the feminist narratives, it is important to take a moment to recognize those as well. While feminist narratives in religious domains are often associated with progressive religious voices, one also finds feminism in evangelical Christianity (Peacore 2010). While identifying with experiential feminist narratives and the need for Christian narratives to incorporate these feminist voices more explicitly, evangelicals also critique feminist narratives that move away from traditional theological ideas such as atonement. In looking at evangelical feminism there is a fear that more progressive feminist narratives lose the grounding of tradition and the power of the traditional narratives to transcend human experience. There is in these narratives an emphasis of the belonging and transformational power of tradition, but one that can be challenged productively by putting them into conversation with experiential feminist narratives (Peacore 2010).

Through this diversity of voices, one finds not only recurring themes across feminist narratives but also places where the fluidity of these narratives begins to provide tools for a transcontextual narrative. These narratives may be based in traditions, but they are not unquestioning narratives. Perhaps one of the most striking themes of many feminist narratives is the willingness to constantly re-examine assumptions about the nature of reality and to revise the narratives to not only reflect that reality but also create that reality as the promotion of justice and human flourishing.

\section{Examples of Masculine Narratives and Anti-Feminist Narratives}

The dialectical engagement of narratives of identity mean that the pre-existing narratives of oppression do not disappear. They are a part of the frames from which people understand the world and are specifically called out by feminist narratives. However, the process of challenging those long held narratives that have defined societies for millennia lead to a dialectical backlash, the anti-feminist and masculinity narrative. As feminism challenges long held narratives and reinterprets them, there is a loss of identity and the risk of the loss of being as a result. So, the backlash leads to a set of narratives that look back to earlier narratives of masculinity through the lens of feminism, but feminism as interpreted by those who feel threatened by it. Masculinity narratives are not necessarily anti-feminist, although they can be. However, one of the challenges of the creation of a transcontextual narrative is the ability to construct narratives that empower and de-marginalize women while not marginalizing not only men but also the notion of masculinity.

In the West, at least, the notion that women are unfinished men and therefore inferior in physical, intellectual, and emotional abilities is deeply embedded in cultural memory (Myers 2015). Cultural memory refers to the way certain ideas become a part of the common understanding of reality. These ideas become embedded in the narratives of communities through continual repetition so that they become a part of the truths of a society and the frames from which meaning is drawn. Take, for example, the stories of Genesis 1-3 in the Hebrew Bible referenced earlier. While the text itself is quite complex with distinct creation narratives and complex relations of humanity to God, within cultural memory in the West the story becomes singular. It is the story of creation where human beings are somehow simultaneously created in the image of God and out of dust, or at least the man is. The woman is created out of a rib bone of the man. Ask any group of students in an introductory religious studies class in the United States and someone will tell you women have one fewer ribs than men, and humanity is punished for the sin of the woman as she tempts the man to eat the apple God told them not to eat. Woman as weak of will but powerful temptress becomes a trope in masculinity narratives that are embedded in cultural memory. What the biblical text says is not as important as what has been passed from generation to generation and in the process becomes truth. Of course, for many students it is and is not truth. Many have assumed the truth of the stories while also not really taking the biology of it too seriously. However, the core elements, the fall of humanity from a state of perfection because the woman tempted the man to eat an apple (or pomegranate as one student in each class will inevitably say), remain a part of the frame that gives meaning within a predominantly Christian leaning U.S. environment. This frame carries so much power that advertisers have long used it to sell precisely the sexuality and temptress quality of women if they will just use the right products (Colette 2015). 
I must also take a moment to indicate a limitation of this study. In the exploration of masculinity and anti-feminist narratives it was often the case that these were not found directly from those holding those narratives but rather by proxy in their responses to feminists or in the reported studies about them. Never the less, there is value to exploring these narratives as they appear all over comments sections of social media and at family gatherings in the continued discussion of \#metoo and related feminist work.

In "'Wronged White Men': The Performativity of Hate in Feminist Narratives about Anti-Feminism in Sweden," Mia Eriksson challenges the universalizing tendency to point to bad white men as the counterpoint to feminism that is a universal good. She critiques the notion that feminism can be divorced from racial discussions while still placing racial markers on the problematic figures, "white men." In the process she uncovers important aspects of an anti-feminist narrative, focusing specifically on Sweden. She references a letter to Politiken where Danish anthropologist Dennis Normark "claims that Swedish feminism has indeed got out of hand. He sees a country where the power balance has shifted and where Swedish men are being oppressed by Swedish women; a country where 'masculine' traits ... are giving way to 'feminine' traits ..." (Eriksson 2013). She describes how "Wronged white men" started as a Facebook group but has developed into a way to delegitimize white male complaints about feminism. In the evaluation of these ideas, Eriksson's concern is with narrative and how a feminist narrative along these lines is performative, creating the reality of hostility toward women it describes and means to overcome. Narrative indicates not only perspective, but repeated enough the narrative creates a world. Eriksson argues that how feminist arguments are constructed matters. If the argument over-generalizes and thus marginalizes and excludes, it creates the conditions for the anti-feminist narratives that then perpetuate the cycle of feminist-anti-feminist conflict. It may even reinforce the very societal structures that caused the gender injustice in the first place and against which feminists fight (Eriksson 2013). Attempts at a kind of feminist meta-narrative such as the one Eriksson is critiquing do not acknowledge the contextual narratives, for example women who are anti-feminist and men who are feminist. A false dichotomy is created that enhances antagonism rather than improving the environment to allow all people to thrive. However, Eriksson's critique is not only of attempts at a feminist meta-narrative. She also identifies the great challenge of feminist narratives, the denial by one who acts in clearly anti-feminist ways is in fact acting that way. There is a kind of glossing over that, according to Eriksson, does violence to the efficacy of the narratives. These claims are found within the feminist meta-narrative and create, according to Eriksson, a picture of Sweden that becomes a narrative people inhabit. Citing Žižek, Eriksson critiques the project of feminist meta-narrative by claiming, "The normality of this order makes any discussion of it redundant; it does not need to reflect upon the violence in its language because this is the normal language, the way 'we' speak about things like hatred, patriarchy, misogyny, sex, gender, and equality. Bodies, relationships, affects, and realities that do not fit this language are, in other words, violently excluded from this feminism and from the reality that it writes" (Eriksson 2013). What Eriksson's analysis provides for the current discussion is not only some insight into masculine and even anti-feminist narratives, but also insight into the limitations of feminist narratives and the ways in which they, if not carefully constructed, can create frames of exclusion rather than inclusion.

The argument against an analysis such as Eriksson's is that the oppression of women does demonstrably happen in the whole of the intersectionality of feminine experience and that there is no obligation to treat the oppressors with kid gloves. However, Eriksson's critique is more nuanced. She sees the oversimplification of "white men" vs. "all of feminism without distinction" as a performative narrative that creates the hostility it seeks to overcome. She says, "If read and written as a figuration, 'wronged white men' confronts feminism with its own assumptions about power, its own blindness towards objective violence, and its own participation in the making of the world (whether this is a world it likes or not). Feminism should, in other words, not be written as a reaction to the worldly forces directed at it, such as patriarchy, but as one part of a worldly configuration" (Eriksson 2013). Eriksson's article therefore both begins the discussion of masculinity and anti-feminist narratives and draws us 
into the next section on the mediating transcontextual narrative. However, before turning there, a little more familiarity with the masculinity and anti-feminist narratives is needed.

Nancy J. Chodorow, in "From the Glory of Hera to the Wrath of Achilles: Narratives of Second -Wave Masculinity and Beyond," identifies the parallel movements of masculinity narratives alongside feminist narratives. The "Glory of Hera" narratives arose out of second-wave psychoanalytic feminism to see the image of an overbearing mother influence that in masculinity narratives becomes distinctively anti-feminist. In proposing the "wrath of Achilles" as an alternative narrative, Chodorow is identifying the tension within masculinity narratives of the alpha male who humiliates or the beta male who is humiliated. In this narrative frame, the secondary role for men puts them in the same category as women and leads to a similar oppression of these men, who have more feminine characteristics, to the oppression of women. One sees not only the competition of masculinity narratives and what it is to "be a man," but also the beginning of intersection between certain types of feminist narratives and certain types of masculinity narratives. Recognizing this conflict and diversity in masculinity narratives is then an important part of the construction of a transcontextual narrative. She states, "The wrath of Achilles, a clinical complex from the time of the Trojan War to now, also has crucial cultural and political consequences. Vamik Volkan (1997) describes how a 13th-century Serb defeat in Kosovo echoes in recent Serbian justifications for invasion and genocide. Kissinger, when asked why he supported the Iraq war, is reported to have said that in the conflict with radical Islam, they want to humiliate us. 'And we need to humiliate them' (reported in Woodward 2006, p. 408)" (Chodorow 2015). In other words, the notion of masculinity breaks down into men who humiliate and men who are humiliated, and you want to be the one who humiliates or you are no better than being a woman. This notion is not only pre-feminist, it is revised in a post-feminist world in anti-feminist narratives. It is deeply embedded in the cultural memory of the West. Examples of it are seen on the large scale in the rhetoric of war and on the small scale in the ways that boys are told not to cry, or run, or throw like a girl. To be girl-like is not only to be inferior and therefore subject to humiliation. To say, "you're such a girl" is to insult a man (Segal 1999). Within this narrative analysis, to lack the will to dominate and humiliate is to embody feminine qualities too much, and therefore to be not a "real man." The "wrath of Achilles" form of masculine narratives are, arguably, at the heart of the need for feminist narratives, not only for the sake of women, but also for the sake of men.

A contemporary variation on this narrative is one in which men are facing the results of the feminist narrative, that women belong in the work place and men should be partners in the home rather than leaving the work of the home to the wife. For some men this condition becomes the source of an anti-feminist narrative. In "The Man Trap", Emily Bobrow describes the challenges the modern man faces in having responsibilities at home with the children and housework while still trying to get ahead at work. This contemporary narrative is a kind of variation on the "wrath of Achilles" narrative in that men who embrace the role of full partner with their wives can find themselves marginalized, becoming the humiliated man who does not have the same opportunities for advancement and raises as men who do not have such responsibilities. The interesting thing about this type of anti-feminist narrative is that it describes women as being able to "have it all" by working and having children, albeit facing fewer opportunities for advancement and raises at work, but for men it means fewer opportunities for advancement and raises at work. In other words, for women it is their job to do those things and they do not need the rewards of career advancement to be considered successful. However, for men in this narrative, to experience the world the way women experience it is a trap that limits their success and overall satisfaction (Bobrow 2018).

One final masculine narrative, albeit given through a feminist lens, is the "white male lie." This narrative encompasses the concerns found embedded in the others. Oluo describes this lie as the promise that white males could be anything they wanted to be. It is a lie because the realities of the world mean that there are a wide variety of inequalities that make the realization of this narrative impossible. Never the less, it is a persistent narrative that the problem of feminism is that it takes something away from men that they were owed. Many feminist arguments defend themselves against 
non-feminist arguments by saying feminism is not about diminishing the rights of men but rather building up the rights of women. However, the "white male lie" is an example of the loss of a right. It may be an unjust right and a problematic assumption, but what Oluo explains is that the assumption is embedded in cultural memory, that white men have a right to be and do whatever they want. So, the loss of the assumed right to dominion over others is in reality the loss of a right. It may be a perceived right rather than actual human right, and it may be at the heart of injustice, marginalization, and inequality. However, it is still perceived as a right and even an absolute right, and therefore something is lost. This systematic and embedded narrative comes out in a variety of aggressive ways against feminist arguments on social media and blogs (Oluo 2018). The result of these narratives is that yet another dialectical move is required if contemporary societies are going to move beyond the aggressive tension between feminist and anti-feminist narratives and the continued marginalization of violence against women. How is it possible, given the opposing perspectives of these narratives, to mediate them into a constructive space where new meanings and realities are created not in spite of, but through the older narratives?

\section{Moving toward the Mediating Frame}

The previous sections challenge our ability to respond to oppression and injustice in anti-feminist narratives. So where does one go from here faced with the complexities of these narratives, their internal inconsistencies and their external aggressions toward each other? There are a variety of feminist writers wrestling with this question. In some sense the overt acts of oppression and sexual violence are easier to address because they are obvious to anyone who claims a feminist narrative. The feminist narratives that are held alongside oppressive or marginalizing behavior are harder to address because of the deep denial that such acts have happened. In addition, the overt acts have their own unique problems of reconciliation because of the anger of the victims and supporters of those victims.

Addressing the overt acts of violence and oppression can perhaps provide us with tools for the subtler acts that are more easily dismissed. Diana Cates is one scholar wrestling with the most difficult forms of overt oppression, rape and torture. In her essay, "Experiential Narratives of Rape and Torture," Cates raises the difficult theological question of forgiveness. The 2002 report from Amnesty International, the Recovery of Historical Memory Project (REMHI), provides accounts of experiences of rape and torture in Guatemala since the 1960s. These narratives are difficult to read not only because of their graphic nature but also because of the ability of the reader to put themselves in the place of the victim. This is the power of narrative, to draw one into the frame of the narrative and see the world through the point of view and meaning giving frames the narrative provides. As Cates describes, the response of the reader to these narratives is anger, rage, hatred. These seem to be natural and even appropriate responses. However, as Cates notes, these are not constructive responses. To wish pain and suffering, even death on the perpetrators of horrific crimes simply perpetuates the estrangement. Forgiveness, as Cates explains, is not easy, and yet it is necessary to move forward to a more inclusive human flourishing.

In describing the report, Cates says,

[The report] represents victim testimonies alongside perpetrator and collaborator testimonies (including, as we have seen, the testimonies of perpetrators who express no shame for what they have done), and comments on all of them with a consistent moral voice-without permitting the dismissal or dehumanization of a single narrator. The effect of this approach is to permit certain emotions, such as hatred for men who rape women, to come to a reader's conscious awareness. The effect is to acknowledge that these emotions are present and powerful, and to let them play an initial role in denunciation. However, the effect is also to provide, repeatedly and consistently, some perspective on these emotions partly through shifts into calmer descriptive or analytical forms of writing (Cates 2010). 
As a virtue ethicist, Cates' concern in our response to these narratives is to promote human flourishing through the cultivation of character. She says, "To invoke the language of virtue ethics, one could say that the report signals the danger of 'too much anger', namely, anger that is experienced in too violent and vindictive a mode, unhinged from the goal of justice" (Cates 2010). If a recurring theme of feminist narratives is a concern with gender justice, then that justice cannot come through alternative acts of injustice or even language that promotes the idea of injustice. Anger at these acts is intense and the narrative that makes sense of the anger and incorporates it into the identity of the angry individual quickly becomes performative, if not by that individual then by proxies as the narrative shapes reality in its externalization. It creates a new nomos that brings a sense of order out of the anomy of rape and torture. Cultivation of virtues can restrain the performative narratives of estrangement and open up the possibilities of performative narratives of reconciliation.

Cates's work can be supported by the tools of positive psychology. Positive psychology arose out of a concern that psychology research focused exclusively on problematic behaviors. However, if problematic behaviors and attitudes can be modified, positive behaviors and attitudes can also be amplified, increasing a sense of happiness and well-being. Rather than a focus on that which divides us and that which we despise about each other, positive psychology demonstrates that we can be as concerned with what goes right in life as in what goes wrong. Seeking common ground and shared space is a place to highlight what goes right and encourages human flourishing. "Positive emotions are more than little extras in life, but are as important for our survival and well-being as the negative emotions that tell us to fight or flee" (Scheib 2014). Tapping into these positive emotions can assist in the creation of transcontextual narratives that invite those who are estranged into reconciliation.

One could point to ways that virtue ethics and positive psychology can become problematic for creating performative transcontextual narratives of reconciliation. There is a risk in virtue ethics with the emphasis on the cultivation of character to become victim blaming or to reinforce power-dynamics that say women must seek reconciliation for the violence done to them. Positive psychology can be seen as placing such an emphasis on positive thinking that it marginalizes genuine suffering. However, the examples used here are very specific applications of both virtue ethics and positive psychology. While almost any theoretical framework for evaluating and shaping human behavior could potentially be used to either include or marginalize people, the examples provided here have specific elements that are moving toward transcontextual narratives that are performative of reconciliation.

In particular, the work on virtue theory by Cates has been carefully crafted to be reconciliatory, but not conciliatory. The claim she is making is that the attitude and character with which we enter a conversation can make or break its ability to be performative of reconciliation. Neither Cates nor I are arguing that anger is an inappropriate reaction, but rather that anger cannot be the only response. What Cates shows in her work is the power of healing made possible by reshaping the narrative by approaching it differently. Recognizing the humanity of another shapes the narrative to be one of recognition of humanity. It becomes an invitation to tell a new collective story by not dehumanizing the other who has dehumanized or at a minimum marginalized me and my experience. Virtue ethics supported by current claims of positive psychology regarding the efficacy of seeking the positive in things provides the background of a transcontextual narrative.

While positive psychology can certainly be used against people as a way to tell them they just need to change their focus in order to live better, that is not how positive psychology is employed here. In this case, positive psychology is used to provide rhetorical tools for the creation of transcontextual narratives of reconciliation. Emphasizing benefits and shared concerns can build bridges. Positive psychology and virtue ethics as described here can be used in the construction of transcontextual narratives by allowing one to see into the narrative of another and extract what is useful in order to build relationships. Not only is a person shaped by their story, their being also shapes the story. If one's character leads one to begin with the humanizing of the other, then so does the narrative one puts out into the world. That narrative then becomes an invitation to the other rather than a warning or a condemnation. 
Lisa Sowle Cahill further develops the tools for the creation of transcontextual narratives that are performative of reconciliation by providing a three-fold hermeneutic for reading tradition: appreciation, suspicion, and praxis (Cahill 2014). Respect for tradition allows feminist narratives to address the language of masculine and anti-feminist narratives. Speaking within the language that is already familiar allows people to feel invited into the frames of meaning by things they recognize and see the respect with which those notions are treated. At the same time, once in this shared space a hermeneutic of suspicion can be employed where negotiation of the unfolding of living and therefore dynamic narratives can happen. Finally, praxis allows the narratives to become performative. In the ritual, ethical, and other shared activities of a community the narratives that give meaning the action become embodied and create new realities.

Biblical scholars are already beginning this process in work such as that done by Alicia D. Myers. In "Jesus and (Re)defining Masculinity in the Gospel of John" she shows appreciation for the tradition and the text itself while applying hermeneutics of suspicion to the cultural memory that Jesus is quintessentially and simply masculine. She claims, "The growing field of gender studies, and especially masculinity studies, has highlighted the consistent presentation of 'masculinity' as the control of self and others, although the proper articulation of control was debated in a variety of ways ... In contrast, 'femininity' is characterized by weakness that prevented self-control. Femininity means permeability, an openness to absorb all influences, especially vice, if not restrained by her masculine superiors" (Myers 2015). In her study of the gospel of John, Myers found that the typical masculinity of Jesus was not as clearly defined as cultural memory would indicate. There is a gender ambiguity in Jesus (Myers 2015). This is not a transcontextual narrative in itself because this kind of challenge to cultural memory as it relates to scripture can be deeply disturbing and enhance masculinity and anti-feminist narratives. Intermediate steps are required between the description of the tradition and the challenging of the tradition. So, the transcontextual narrative requires a modification of Sowle Cahill's framework.

For this modification, I return to Richard Kearney. The five moments of anatheism he describes_imagination, humor, commitment, discernment, and hospitality—can be used to fill in the gap created between appreciation and suspicion. A transcontextual narrative must begin with an appreciation of the traditions of both feminist and masculinity and anti-feminist narratives. The language must be recognizable in order for the frames to give rise to meaning. However, in pulling together different frames that may use the same language, which we have seen in the feminist and anti-feminist narratives, new meanings can be constructed. It requires creative and imaginative reconfiguration of the elements of the narrative that recognize the value of the previous narrative frames while also recognizing their limitations. It requires humor in the ability to speak thoughtfully with rather than at those with whom one disagrees. Returning to Cates, humor may be a virtue here, a cultivation of our character to not give in to anger in order to see ourselves and others more clearly. It requires commitment to stay in the conversation even when it is difficult while not becoming reactive. Group narrative construction requires dialogue. It requires discernment in the ability to see past the surface of the language being used to the being of the other in the conversation and how the narrative expresses and shapes the being of the other. To see from another person's point of view shows a respect and care for the other that invites them into the conversation. In that invitation into a new frame hospitality is performed. In addition, in performing hospitality it may become possible for the new narrative to become performative, to reshape a collective reality beyond feminist and anti-feminist narratives and yet not beyond. It is a reframing of feminist narratives after the new anti-feminist and masculinity narratives, not in spite of them, but together with their critiques of feminism. Creating the hospitable space opens the doors for a shared hermeneutics of suspicion, not of each other, but of oneself. Praxis becomes the performance of the narrative, the recreation of collective being through the reconfiguration of narrative. 


\section{Conclusions}

The creation of the transcontextual narrative that is performative of reconciliation is possible in part because narratives are not static. Human life is constantly unfolding in an ever-changing environment to which one must adapt in order to survive. The narratives that give being and identity to individuals and communities must also adapt. Narratives that cannot change become irrelevant and die. They are replaced by others that speak to the needs of the people at the time. This process of reconfiguration, (Caufield 2015) as Ricoeur described it, can be traced through the centuries. Part of the resistance to feminist narratives is in the ways they challenge what are taken to be "traditional" roles of men and women seen as ordained by God. Men who feel their stories threatened feel their roles and their identity, and therefore their very being, to be threatened. Who are they if the narratives are not true? However, the question we should be asking is not about the truth or falsehood of the narratives, but rather their ability to allow people to function together and to flourish as human beings. Recognition first of the diversity of narratives in masculinity, anti-feminism, and feminism can allow people to take the risk of stepping into a shared space of reconfiguration. The narrative must be inviting, but the step into the space is a choice based on one's own desire or not for the flourishing of all people. While such work of creating these spaces is experimental, the place to begin is with individual conversations and slowly building networks of narratives. Performative narratives of reconciliation are much slower than performative narratives of exclusion, in part because they are building new frames. We see examples of this kind of framing in religious texts where symbols blended in a particular way provide new meanings for people. While social media can be a challenging place to navigate, engaging people in language they understand and through media that reaches them while thoughtfully reframing that language can be a way to create spaces of inclusion on a broader scale.

Conflicts of Interest: The author declares no conflicts of interest.

\section{References}

Avishai, Orit. 2016. Theorizing Gender from Religion Cases: Agency, Feminist Activism, and Masculinity. Sociology of Religion: A Quarterly Review 77: 261-79. [CrossRef]

Bobrow, Emily. 2018. The Man Trap. The Economist. Available online: https:/ /www.1843magazine.come/features / the-man-trap (accessed on 29 January 2018).

Brady, Judith Ann O.P. 2008. Letty M. Russell: A Feminist Liberation Approach to Educating for Justice. Religious Education 103: 179-95. [CrossRef]

Cahill, Lisa Sowle. 2014. Catholic Feminists and Traditions: Renewal, Reinvention, Replacement. Journal of the Society of Christian Ethics 34: 27-51. [CrossRef]

Cates, Diana Fritz. 2010. Experiential Narratives of Rape and Torture. Journal of Religious Ethics 38: 43-66. [CrossRef]

Caufield, Catherine L. 2015. Disruptive Narratives of Jesus: Feuerbach and Ricoeur in Dialogue. Bulletin for the Study of Religion 44: 26-35. [CrossRef]

Chodorow, Nancy J. 2015. From the Glory of Hera to the Wrath of Achilles: Narratives of Second-Wave Masculinity and Beyond. Studies in Gender and Sexuality 16: 261-70. [CrossRef]

Christ, Carol P. 2011. Community and Ambiguity: A Response from a Companion in the Journey. Journal of Feminist Studies in Religion 27: 29-34. [CrossRef]

Colette, Shelly. 2015. Eroticizing Eve: A Narrative Analysis of Eve Images in Fashion Magazine Advertising. Journal of Feminist Studies in Religion 31: 5-24. [CrossRef]

Downey, Martha Elias. 2012. Perspective on Narrative Theology: Its Purpose, Particularity, and Centrality. Theoforum 43: 291-307.

Ehret, Verna. 2013. Utopia and Narrative: Theology between the Boundaries of Overhumanization and Hypertheism. In Resisting the Place of Belonging: Uncanny Homecomings in Religion, Narrative and the Arts. Edited by Daniel Boscaljon. Farnham: Ashgate Press, pp. 73-86. ISBN 1409453944.

Eriksson, Mia. 2013. 'Wronged White Men': The Performativity of Hate in Feminist Narratives about Anti-Feminism in Sweden. Nordic Journal of Feminist and Gender Research 21: 249-63. [CrossRef] 
Gehlin, Sara. 2010. Quest for Unity, Quest for Diversity: Ecumenical Challenges in a Time of Globalization. The Ecumenical Review 62: 308-16. [CrossRef]

Guth, Karen V. 2015. Doing Justice to the Complex Legacy of John Howard Yoder: Restorative Justice Resources in Witness and Feminist Ethics. Journal of the Society of Christian Ethics 35: 119-39. [CrossRef]

Hamblin, James. 2018. This is Not a Sex Panic: Stories of Gray areas are exactly what more men need to hear. The Atlantic. Available online: https:/ / www.theatlantic.com/entertainment/archive/2018/01/this-is-not-asex-panic/550547/ (accessed on 18 January 2018).

Hamid, Shadi. 2006. Between Orientalism and Postmodernism: The Changing Nature of Western Feminist thought Towards the Middle East. Hawwa 4: 76-92. [CrossRef]

Jovic, Rastko. 2015. Doing Gender Justice as a Mission Imperative: God's Justice and Ours. International Review of Mission 104: 26-36. [CrossRef]

Klemm, David, and Schweiker William. 2008. Religion and the Human Future: An Essay on Theological Humanism. Oxford: Wiley-Blackwell Press, ISBN 978-1405155274.

Kearney, Richard. 2010. Anatheism: Returning to God after God. New York: Columbia University Press, ISBN 9-780231147897.

Lange, Dirk G. 2016. Calling upon the Name of God: Father as Metaphor. Word $\mathcal{E}$ World 36: 82-85.

Myers, Alicia D. 2015. Gender, Rhetoric and Recognition: Characterizing Jesus and (Re)defining Masculinity in the Gospel of John. Journal for the Study of the New Testament 38: 191-218. [CrossRef]

Nienhuis, Nancy E. 2009. Taming 'Wild Ass-Colts': An Analysis of Theology as a Kyriarchal Weapon of Spiritual and Physical Violence. Journal of Feminist Studies 25: 43-64. [CrossRef]

Oluo, Ijeoma. 2018. The Anger of the White Male Lie. Medium. Available online: https://medium.com/ @IjeomaOluo/the-abger-of-the-white-male-lie-6f9a6e646d47 (accessed on 22 March 2018).

Peacore, Linda D. 2010. An Evangelical Feminist Perspective on Traditional Atonement Models. Ex Auditu 26: 145-63.

Pineda-Madrid, Nancy. 2011. Celebrating Our Latina Feminist Foremothers: A Response to Elisabeth Schüssler Fiorenza. Journal of Feminist Studies in Religion 27: 110-14. [CrossRef]

Poloni-Staudinger, Lori, and Candice Ortbals. 2014. Gendering Abbottabad: Agency and Hegemonic Masculinity in an age of Global Terrorism. Gender Issues 31: 34-57. [CrossRef]

Powell, Lisa D. 2015. The Infertile Womb of God: Ableism in Feminist Doctrine of God. Crosscurrents 65: 116-38. [CrossRef]

Rigoglioso, Marguerite. 2011. Envisioning a Spiritualized Feminist The*logical Tradition: Being the Change We Want to See. Journal of Feminist Studies in Religion 27: 105-9. [CrossRef]

Rodriguez, Ana Patricia. 2008. The Fiction of Solidarity: Transfronterista Feminisms and Anti-Imperialist Struggles in Central American Transnational Narratives. Feminist Studies 34: 199-226.

Scheib, Karen. 2014. All Shall Be Well: Flourishing and Well-being in Positive Psychology and Feminist Narrative Pastoral Theology. The Journal of Pastoral Theology 24: 2.1-2.17. [CrossRef]

Schüssler Fiorenza, Elisabeth. 2011. Celebrating Feminist Work by Knowing It. Journal of Feminist Studies in Religion 27: 97-127. [CrossRef]

Segal, Lynne. 1999. Cautionary Tales: Between Freud and Feminism. Constellations: An International Journal of Critical \& Democratic Theory 6: 61-79.

Southern Poverty Law Center. 2017. FBI: Hate Crimes Hit Five-Year High in 2016, Jumped as Trump Rolled toward Presidency. Available online: https:/ /www.splcenter.org/hatewatch/2017/11/13/fbi-hate-crimesreach-5-year-high-2016-jumped-trump-rolled-toward-presidency-0 (accessed on 31 March 2018).

Wood, Holly. 2018. Fucking in the Hell that is Aziz Ansari's Modern Romance. Medium. Available online: https:/ / medium.com/@girlziplocked/fucking-in-the-hell-that-is-aziz-ansaris-modern-romancecbc4d1edf771 (accessed on 1 February 2018).

Yang, Sunggu. 2016. The Abrahamic pilgrimage story in sermons: An ontological-narrative foundation of Asian American life in faith. Theology Today 73: 24-35. [CrossRef]

(C) 2018 by the author. Licensee MDPI, Basel, Switzerland. This article is an open access article distributed under the terms and conditions of the Creative Commons Attribution (CC BY) license (http:/ / creativecommons.org/licenses/by/4.0/). 